\title{
Change in Historical Range of the Ural Owl in Europe
}

\section{Quentin Goffette ${ }^{1, *}$, Marceline Denis ${ }^{2}$, Nadja Pöllath ${ }^{3} \&$ Wim Van Neer ${ }^{1}$}

\author{
1 Operational Direction 'Earth and History of Life', Royal Belgian Institute of Natural Sciences, Vautier street 29, B-1000 \\ Brussels, Belgium. \\ 2 Service public de Wallonie, DGO4, Département du Patrimoine, Direction du Hainaut-I, Service de l'archéologie, Place \\ du Béguinage 16, B-7000 Mons, Belgium. \\ 3 Institute of Palaeoanatomy, Domestication Research and History of Veterinary Medicine, Ludwig-Maximilians-Univer- \\ sity of Munich, Kaulbachstraße 37 III/313, D-80539 Munich, Germany \\ * Corresponding author: quentin.goffette@naturalsciences.be
}

\begin{abstract}
A carpometacarpus recovered during archaeological excavations in the town of Quaregnon is the westernmost find ever reported in Europe of a Ural Owl (Strix uralensis), and the first occurrence for Belgium. Both the morphology of the skeletal element and its measurements rule out an identification as any of the other Strigiformes from the Western Palearctic. The provenance of this specimen, that dates to the medieval period (10th-12th centuries AD), is discussed. It is hypothesized that the bird was a wild animal, but the available evidence does not unequivocally determine whether it belonged to a local, breeding population that went extinct or if it came from a more distant population. However, a survey of other zooarchaeological finds of Ural Owl in Europe shows that the species occurred farther west in the past, outside the present natural breeding range. This suggests that Ural Owl may have found suitable nesting biotopes in Belgium and northern France during the medieval period.
\end{abstract}

KEY-WORDS: biogeography, bird, Strix uralensis, Ural Owl, zooarchaeology

\section{INTRODUCTION}

Faunal remains recovered from archaeological excavations allow reconstruction of subsistence strategies of past human populations, but also provide information on the ancient distribution of animal species. In this respect, when studying archaeological bird remains, it is important to keep in mind that species may occur that are not part of the current local avifauna (STEWART, 2005). Zooarchaeological evidence for taxa that are not native to the region of the archaeological site where they were discovered can often be explained as a result of trade. Alternatively, zooarcheological findings can indicate changes in species distribution ranges through time, either due to climatic or anthropic factors. For example, NiKUlinA \& SCHMÖLCKE (2015) used subfossil bones to show that birds of the genus Pelecanus occurred far out of their present range between 7.4 and $5.0 \mathrm{ka} \mathrm{BP}$ (thousand years before present) in the Danish archipelago.
This type of information is valuable for the documentation of climate change and human impacts through time, and can be relevant to conservation biology (LYMAN, 2006; for a recent example see STEWART, 2007). Here we collate archaeological finds of a strigiform species and discuss its zoogeographical relevance after the compilation of zooarchaeological reports from Europe that are not easily accessible to the wider ornithological community.

In 2008 and 2009, archaeological excavations were carried out by the Service public de Wallonie at the 'Grand' Place' of Quaregnon (DENIS, 2010; DENIS, 2011), a town situated in the southwest of Belgium at $\sim 6 \mathrm{~km}$ west of the city of Mons (Fig. 1). Quaregnon (50²6’34” $\mathrm{N}, 3^{\circ} 51 ' 56^{\prime}$ E) is located in the Haine valley, at 33 meters above sea level. During the 2008 campaign, a carpometacarpus of a strigiform was discovered in a medieval settlement. The ditch surrounding an ancient church, in which 
this bone was found also yielded a few remains of the usual food animals (cattle, pig, sheep, chicken) and some human bones from nearby disturbed graves (GOFFETTE et al., 2015). Unlike the other animal remains, which are considered as human consumption refuse, the strigiform bird is believed to be part of a discarded carcass (GAUTIER, 1987). Associated artefacts date the filling to the 9th-11th centuries AD.

\section{MATERIAL AND METHODS}

The bone discovered in Quaregnon was initially identified to genus level with the aid of the diagnostic criteria described in LANGER (1980) and by comparison with the modern reference collections of the Royal Belgian Institute of Natural Sciences (RBINS) and of the Royal Museum of Central Africa (RMCA), presently also housed at the RBINS. In addition to the measurements taken on the RBINS/RMCA specimens, other carpometacarpus dimensions were obtained from the Regalia collection (Institut de Paléontologie Humaine, Muséum national d'Histoire naturelle (MNHN), Paris) and from the Staatssammlung für Anthropologie und Paläoanatomie München (SAPM) for Ural Owl Strix uralensis PALLAS, 1771 and from the Institute of Systematics and Evolution of Animals (Polish Academy of Sciences (PAS), Warsaw) for Ural Owl and Short-eared Owl Asio flammeus (PONTOPPIDAN, 1763). Measurements were taken with digital callipers following the recommendations of VON DEN DRIESCH (1976). The descriptions of anatomical features below follow the nomenclature of BAUMEL (1993).

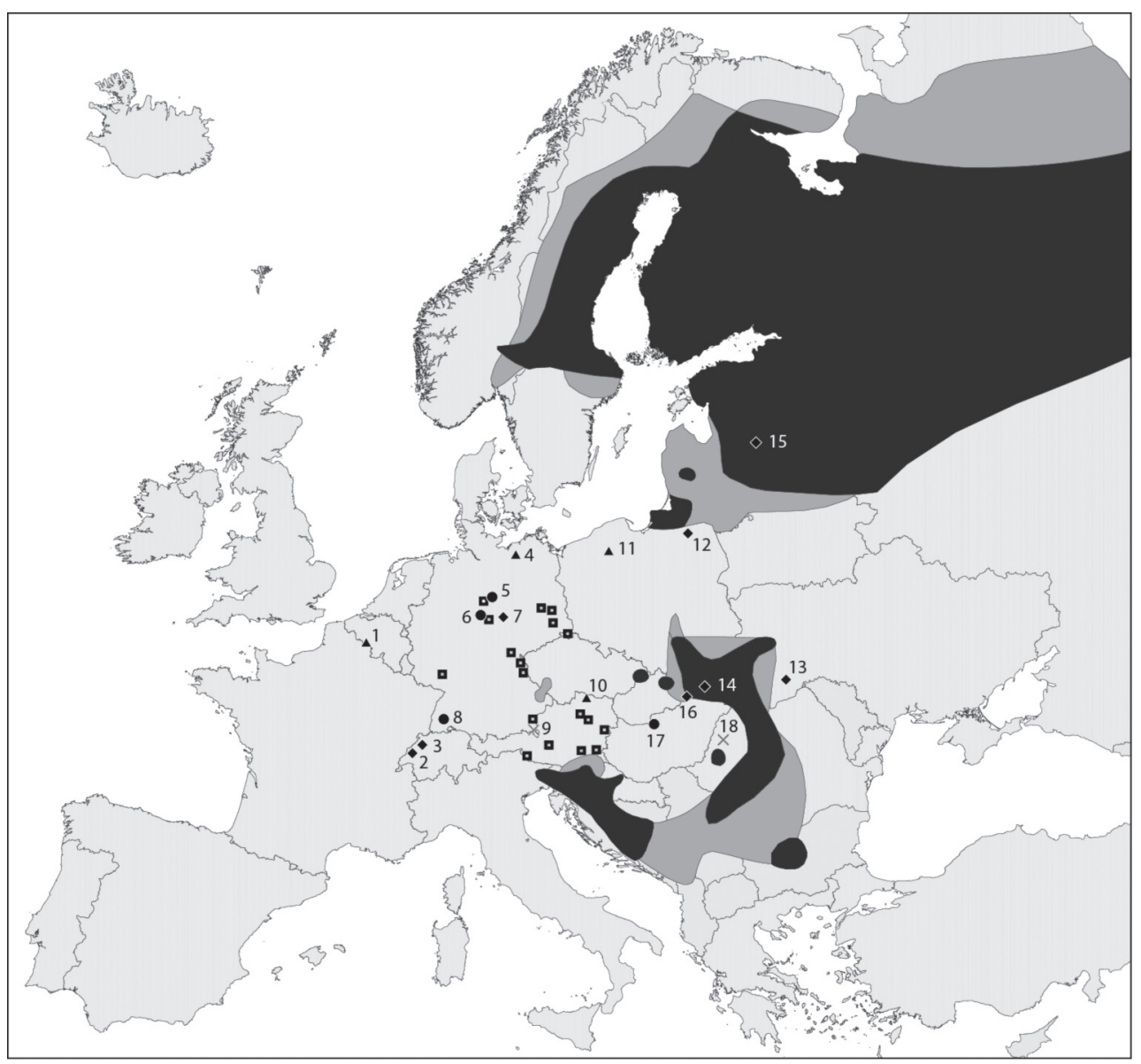

Fig. 1. - Present distribution of Ural Owl (black areas - main distribution range, grey areas - periphery of the distribution, hollow squares - single observations) and zooarchaeological discoveries in Europe (diamonds $9000 \mathrm{BC}-1000 \mathrm{BC}$, circle - $1000 \mathrm{BC}-600 \mathrm{AD}$, triangle - 600-1800 AD, cross - indeterminate). The numbers correspond to those of the archaeological sites mentioned in Table 2. Map modified after SCHERZINGER (2006). 
The strigiform bone has been radiocarbon dated in order to confirm its contemporaneity with the associated artefacts. Only the mid-part of the carpometacarpus was used, the two extremities are still intact and stored in the collections of the RBINS. No palaeogenetic analysis has been attempted on this bone thus far. It is believed that such molecular data would be of little help in determining its provenance because of the high genetic diversity observed within each of the present-day European populations of Ural Owl (HAUSKNECHT et al., 2014).

\section{RESULTS}

The strigiform bone discovered is an almost complete left carpometacarpus of which only the proximodorsal part of the os metacarpale minus was slightly damaged (Fig. 2). The fresh aspect of the fractured part suggests that it was broken during the excavation. The bone surface is very well preserved, but no anthropogenic traces (e.g., cut marks) were observed despite careful examination with binocular microscope (magnification $20 \mathrm{x}$ ). When comparing the specimen with the skeletons of strigiforms presently found in Belgium, it appears that the Short-eared Owl is the closest in size. However, the carpometacarpus from Quaregnon appears less elongated and more robust because of the shorter and wider spatium intermetacarpale. The os metacarpale majus is also wider and less straight, because the lateral border slightly curves laterally close to the processus alularis. The os metacarpale minus is thicker and curved. The distal epiphysis is larger and more robust compared to that of the Short-eared Owl. In particular the facies articularis digitalis major is more robust and is laterally more protruding. The facies articularis digitalis minor projects more in a distal direction compared to the Short-eared Owl. In proximal view, the trochlea carpalis is thick and the two cristae of the trochlea are almost parallel, unlike in Short-eared Owl where the dorsal crista is oblique in a laterodorsal direction. The aforementioned morphological features of the bone are typical of the genus Strix.

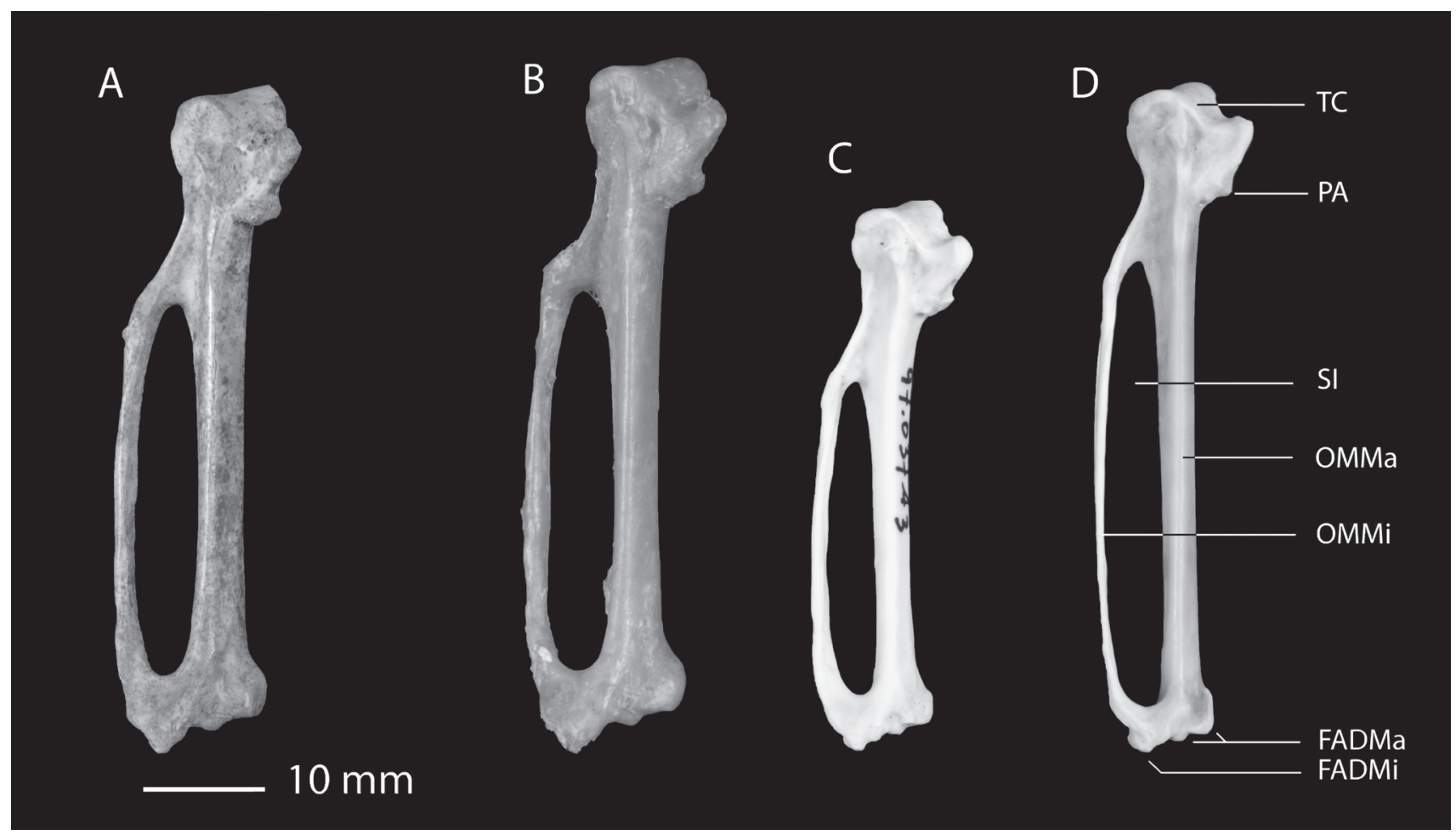

Fig. 2. - Carpometacarpus from: A. Ural Owl from Quaregnon. B. Modern Ural Owl (RBINS 20655). C. Modern Tawny Owl (RMCA 97037A3). D. Modern Short-eared Owl (RBINS 80531). TC - Trochlea carpalis, PA Processus alularis, SI - Spatium intermetacarpale, OMMa - Os metacarpale majus, OMMi - Os metacarpale minus, FADMa - Facies articularis digitalis major, FADMi - Facies articularis digitalis minor. 
Within the genus Strix, four species occur nowadays in the Western Palearctic (sensu Cramp \& Simmons, 1977): Tawny Owl Strix aluco L., 1758, Ural Owl, Hume's Owl Strix butleri (HuME, 1878) and Great Grey Owl Strix nebulosa FORSTER, 1772. Comparisons with the reference collections of the RBINS/RMCA and with published measurements (LANGER, 1980) show that the carpometacarpus of the Tawny Owl is too small. Consequently, Hume's Owl, the smallest species of this genus in the Western Palearctic, can also be excluded. The Great Grey Owl, which is the largest Strix species in the Western Palearctic, is definitely too large compared to the Quaregnon specimen. However, the measurements of the archaeological carpometacarpus fall exactly within the variation of Ural Owl (Fig. 3 and Table 1). The metrical data also show that the Short-eared Owl, which was already excluded on a morphological basis, is somewhat smaller compared to the Quaregnon specimen and Ural Owl in general. To conclude, both morphological features and dimensions indicate that the fossil carpometacarpus from Quaregnon belongs to the Ural Owl.
The AMS radiocarbon date obtained directly on the Ural Owl bone from Quaregnon (993 \pm 32 BP, RICH-21621) validates the relative dating based on the associated archaeological material. The calibrated results provide a chronological range between the 10th and 12th centuries $A D$, which is slightly more recent than the date indicated by the archaeological material (9th11 th centuries $\mathrm{AD})$ :

$\begin{array}{ll}\text { Calibrated (1 } \sigma) & 990 \mathrm{AD}(60.7 \%) 1050 \mathrm{AD} \\ & 1090 \mathrm{AD}(7.5 \%) 1120 \mathrm{AD} \\ \text { Calibrated }(2 \sigma) & 980 \mathrm{AD}(95.4 \%) 1160 \mathrm{AD}\end{array}$

\section{DISCUSSION}

The Ural Owl is a polytypic species that is nowadays widespread across the entire Palearctic (CRAMP, 1985; MEBS \& SCHERZINGER, 2006). Within the Western Palearctic (Fig. 1) its range extends from Finland in the north to Bulgaria in the south and from Norway in the west to the eastern border of the Western Palearctic in the east (and further up to the Pacific Ocean, see DEL HoYo et al., 1999). Between 1976 and 1993, birds have been successfully reintroduced in Bavaria,

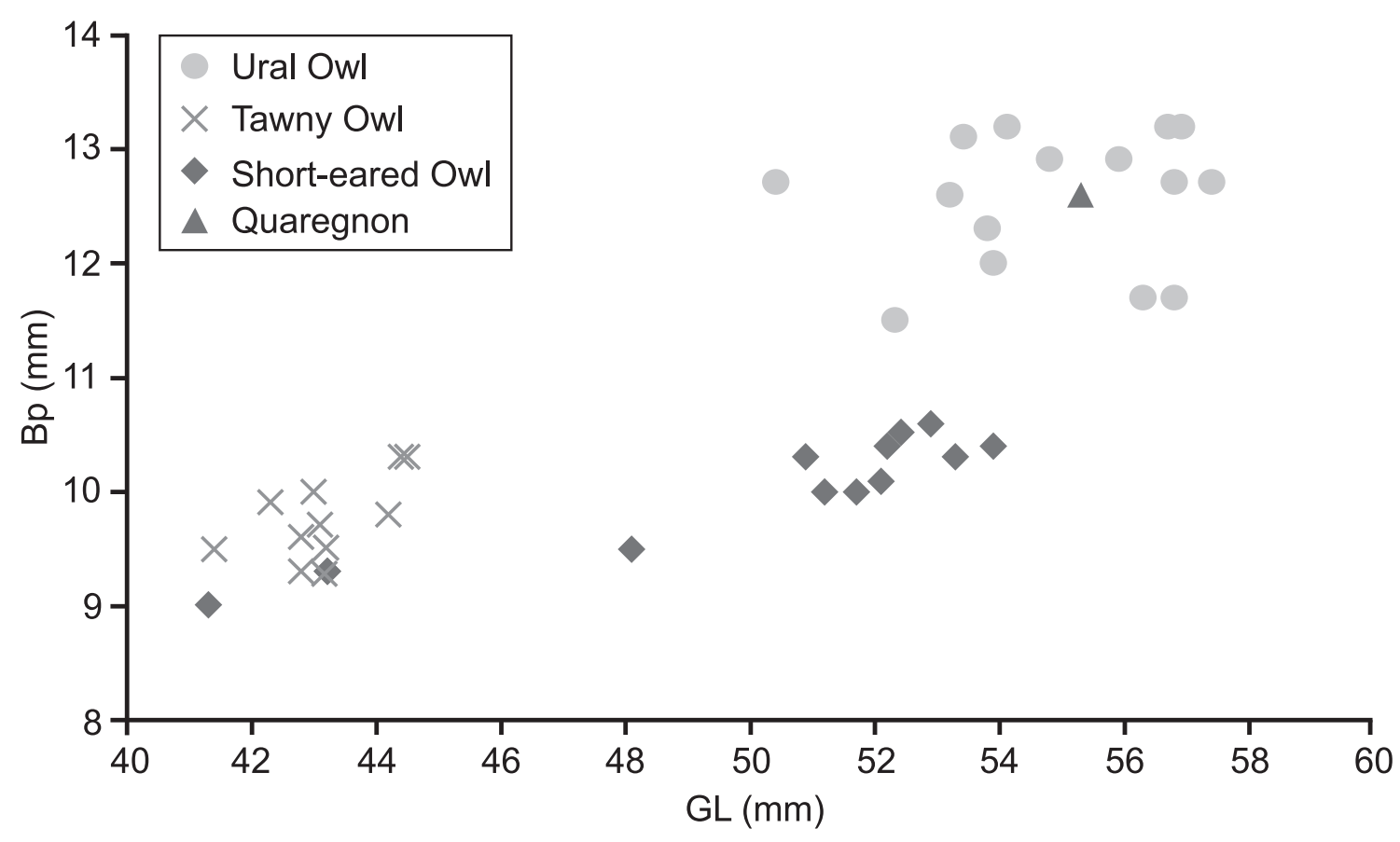

Fig. 3. - Plot of the greatest breadth of the proximal extremity (Bp) and the greatest length (GL) of the Ural Owl carpometacarpus from Quaregnon and those of modern specimens of Ural Owl, Tawny Owl and Short-eared Owl (list of specimens and measurements in Table 2). 


\section{TABLE 1}

Measurements (in mm) of the Ural Owl carpometacarpus from Quaregnon, compared to those of museum specimens of the same species and of Short-eared Owl, Tawny Owl and Great Grey Owl. Measuring distances and their abbreviations are according to VON DEN DRIESCH (1976): GL = Greatest length; Bp = Greatest breadth of the proximal extremity; Did = Diagonal of the distal end. MNHN = Regalia collection, Institut de Paléontologie Humaine, Muséum national d'Histoire naturelle, Paris; PAS = Institute of Systematics and Evolution of Animals, Polish Academy of Sciences, Warsaw; RBINS = Royal Belgian Institute of Natural Sciences, Brussels/Royal Museum for Central Africa, Tervuren; SAPM = Staatssammlung für Anthropologie und Paläoanatomie, München. Measurements ranges for Great Grey Owl are from CAMPBELL \& BOCHEŃSKI (2010).

\begin{tabular}{|c|c|c|c|c|}
\hline Species & Specimen $n^{\circ}$ & GL & Bp & Did \\
\hline Ural Owl (Strix uralensis) & Quaregnon Z01 F97 SU01.242 & 55.3 & 12.6 & 10.8 \\
\hline Ural Owl (Strix uralensis) & PAS 5752/99 & 56.6 & 12.3 & 11.8 \\
\hline Ural owl (Strix uralensis) & PAS $2767 / 73$ & 53.8 & 11.7 & 10 \\
\hline Ural owl (Strix uralensis) & PAS 7290/10 & 56.8 & 12.7 & 11.5 \\
\hline Ural owl (Strix uralensis) & PAS 6787/07 & 57.4 & 12.9 & 11.1 \\
\hline Ural owl (Strix uralensis) & PAS 6000/02 & 55.9 & 13.2 & 11.8 \\
\hline Ural owl (Strix uralensis) & PAS 6786/07 & 56.7 & 12.7 & 11.5 \\
\hline Ural owl (Strix uralensis) & MNHN 569 & 56.8 & 13.2 & 11.4 \\
\hline Ural owl (Strix uralensis) & MNHN 689 & 56.9 & 13.2 & 11.3 \\
\hline Ural owl (Strix uralensis) & MNHN 970 & 54.1 & 11.7 & 10 \\
\hline Ural owl (Strix uralensis) & RBINS 20655 & 56.3 & 12.9 & 11.4 \\
\hline Ural owl (Strix uralensis) & SAPM 6 & 54.8 & 13.1 & 11.2 \\
\hline Ural owl (Strix uralensis) & SAPM 7 & 53.4 & 12 & 10.9 \\
\hline Ural owl (Strix uralensis) & SAPM 8 & 53.9 & 12.7 & 10.9 \\
\hline Ural owl (Strix uralensis) & SAPM 9 & 50.4 & 11.5 & 10.3 \\
\hline Ural owl (Strix uralensis) & SAPM 10 & 52.3 & 12.6 & 10.9 \\
\hline Ural owl (Strix uralensis) & SAPM 11 & 53.2 & 13 & 11.2 \\
\hline Tawny Owl (Strix aluco) & RBINS 93030A01 & 43.2 & 9.5 & 8.5 \\
\hline Tawny Owl (Strix aluco) & RBINS 92017A03 & 43.2 & 9.3 & 8.5 \\
\hline Tawny Owl (Strix aluco) & RBINS 99062A03 & 43 & 10 & 8.6 \\
\hline Tawny Owl (Strix aluco) & RBINS 82574 & 44.4 & 10.3 & 9.2 \\
\hline Tawny Owl (Strix aluco) & RBINS 97048A19 & 44.2 & 9.8 & 8.5 \\
\hline Tawny Owl (Strix aluco) & RBINS 97037A03 & 44.5 & 10.3 & 8.7 \\
\hline Tawny Owl (Strix aluco) & RBINS 96004A03 & 43.1 & 9.7 & 8.4 \\
\hline Tawny Owl (Strix aluco) & RBINS 82611 & 44.2 & 9.8 & 8.8 \\
\hline Tawny Owl (Strix aluco) & RBINS 82716 & 42.8 & 9.3 & 8.3 \\
\hline Tawny Owl (Strix aluco) & RBINS 99086A06 & 42.3 & 9.9 & 8.4 \\
\hline Tawny Owl (Strix aluco) & RBINS 77242 & 41.4 & 9.5 & 8.2 \\
\hline Tawny Owl (Strix aluco) & RBINS 96009A01 & 42.8 & 9.6 & 8.6 \\
\hline Great Grey Owl (Strix nebulosa) & number of specimens $=8$ & $60.1-68.2$ & $13.6-15.6$ & $10.9-12.6$ \\
\hline Short-eared Owl (Asio flammeus) & PAS 5479/96 & 52.1 & 10.1 & 7.2 \\
\hline Short-eared Owl (Asio flammeus) & PAS $2533 / 72$ & 51.2 & 10 & 6.9 \\
\hline Short-eared Owl (Asio flammeus) & PAS 3084/75 & 48.1 & 9.5 & 6.9 \\
\hline Short-eared Owl (Asio flammeus) & PAS 5745/99 & 43.2 & 9.3 & 7.3 \\
\hline Short-eared Owl (Asio flammeus) & PAS $3083 / 75$ & 41.3 & 9 & 7.1 \\
\hline Short-eared Owl (Asio flammeus) & PAS 7085/08 & 51.7 & 10 & 7.6 \\
\hline Short-eared Owl (Asio flammeus) & RBINS 92138A04 & 52.2 & 10.4 & 7.4 \\
\hline Short-eared Owl (Asio flammeus) & RBINS 96074A07 & 52.9 & 10.6 & 7.4 \\
\hline Short-eared Owl (Asio flammeus) & RBINS 77291 & 52.4 & 10.5 & 7.8 \\
\hline Short-eared Owl (Asio flammeus) & RBINS 80531 & 53.9 & 10.4 & 7.9 \\
\hline Short-eared Owl (Asio flammeus) & RBINS 81084 & 50.9 & 10.3 & 7.4 \\
\hline Short-eared Owl (Asio flammeus) & RBINS 80532 & 53.3 & 10.3 & 7.8 \\
\hline
\end{tabular}


Germany, where the species was breeding until 1925, and the same has been done in the Czech Republic from 1995 onward (MEBS \& SCHERZINGER, 2006). Ural Owls are sometimes observed outside their present breeding range (Fig. 1), as was the case in western Germany or in north-eastern Italy where the species bred in 1994 (MEBS \& SCHERZINGER, 2006).

The present, highly fragmented distribution in Western Europe is believed to represent the relics of a wider distribution during the last glacial period (MEBS \& SCHERZINGER, 2006; BASHTA, 2009). In addition, the species' distribution was still contracting as late as the beginning of the 20th century $A D$, especially because of human persecution (SCHERZINGER, 2006). The striking patchiness of the current populations would thus represent the remaining suitable biotopes acting as cryptic southern refugia (STEWART et al., 2010) where the species has not been too much disturbed, including mainly semi-mountainous areas in western and southern Europe.

To explain the presence of the Ural Owl bone in Quaregnon, two possibilities need to be considered: a captive bird brought in by humans or a wild bird. Firstly, the specimen may have been brought in by humans from another area within the natural breeding range of the species. The find from Quaregnon dates to a period when human population movements and long distance trade were frequent in Europe. Those networks of transfers of goods and people included regions where the Ural Owl breeds today, such as Fennoscandia and the Baltic countries. People travelling from those areas to Western Europe could have been carrying either a living Ural Owl or a whole or partial carcass. In medieval times, birds of prey were sometimes traded and transported over long distances to be used for falconry (OGGINS, 2004). Evidence for such practices has been found, for instance, in Winchester (England) where bones of at least two Gyrfalcons Falco rusticolus L., 1758 were discovered in archaeological contexts dating to the 11-12th centuries AD. The birds are believed to have been imported from Norway or Iceland
(SERJEANTSON, 2006). Although many species have been trained for falconry, we found no data in the literature referring to the use of Strigiformes for this purpose in Europe. Owls, probably mainly Eurasian Eagle Owl Bubo bubo (L., 1758) have been exploited as lures to hunt other bird species (JAQUES \& DoBNEY, 2002; TYRBERG, 2002) but not to catch prey. It therefore seems unlikely that the Ural Owl from Quaregnon was brought in as a captive bird meant for falconry. Alternatively, it could have been imported as a curiosity or a pet, but no evidence for this is available. Moreover, it should be underlined that no artefacts were found on the entire archaeological site that could attest the inhabitants possessed items obtained through long distance trade.

The other possibility involves a bird of wild origin. Although the Ural Owl nests preferentially in coniferous forests within the northern and eastern part of its range and in beech (Fagus sp.) forests in its southern distribution area, it is relatively tolerant to the tree species composition of its habitat (CRAMP, 1985; MEBS \& SCHERZINGER, 2006). It avoids intensively exploited forests where human disturbance is strong. Such forests are unlikely to provide suitable nesting places, such as broken tree stumps or hollow trunks where the nests are most frequently built (VREZEC \& TOME, 2004). In this respect, the age of woodlands is of importance because trees need to be large and thus old enough to support the nests (LUNDBERG \& Westman, 1984; BolbOACA et al., 2013). Altitude seems of less importance since nests have been recorded from 160 m.a.s.l. in Slovakia up to 1600 m.a.s.1. in Romania (CRAMP, 1985; KRISTIN et al., 2007). As the species requires open places to hunt, nests are generally situated near woodland margins or within clearances (MEBS \& SCHERZINGER, 2006). CRAMP (1985) notes that this owl is commonly found near human settlements, and that it favours extensive cultivation and pasture land. It is sometimes found within towns, particularly during winter.

Thus far archaeobotanical data that could document the medieval or post-medieval 
environment of Quaregnon are lacking, but general information on the historical land cover in the region suggests that the species may have found suitable habitats to nest. During the early Roman period, woodlands in the southern part of Belgium suffered significant degradation. Towards the end of the Roman period and at the beginning of the medieval period (Merovingian times) forests recovered but deforestation started again later in the Early Middle Ages (Carolingian period) (VANPOUCKE et al., 2007). However, historical sources indicate that vast deciduous forests still existed south of Quaregnon during the medieval period and until the 16th century AD (VERHUlst, 1999). This type of old deciduous forests probably met the ecological requirements of the Ural Owl. Even if some clearance of woodland had taken place, this would not necessarily have been detrimental to the species as it takes advantage of the newly created open landscapes to prey on small mammals (MEBS \& SCHERZINGER, 2006). Shortly after, intensive logging started and at the end of the 18th century, as shown by the maps of FERRARIS (1771-1778), the landscape was turned into agricultural land almost comparable to the present state.

Further supportive of a local origin of the Quaregnon specimens is that Ural Owls have been found to be extremely sedentary, very rarely wandering outside their breeding range (MikkolA, 1983). Indeed, Finnish ringing records comprising a total of 58410 Ural Owls collected between 1913 and 2012 show that more than $90 \%$ of Ural Owls breed within a radius of 3 $\mathrm{km}$ from year to year (i.e. in the same territory). In Finland, the longest distance between two successivenest sites has been $\sim 300 \mathrm{~km}$ (VALKAMA et al., 2014). However, some Ural Owls have been reported to occasionally travel up to more than a thousand kilometres (DORNBUSCH, 1990) and in Siberia, such long distance movements are not uncommon (MiKKOLA, 1983; MEBS \& SCHERZINGER, 2006; CRAMP 1985). Therefore, although unlikely, it cannot be totally excluded that the bird discovered in Belgium could have been a migratory or vagrant bird.
Other zooarchaeological finds are known of Ural Owl outside its present-day breeding range. We compiled the Holocene finds listed in larger inventories such as those of PIEHLER (1976), of KESSLER (2014) and of von den DRIESCH \& Pöllath (2010, see also BENECKE, 1999) with other data we found in the zooarchaeological literature. Find localities are indicated on Fig. 1 and detailed in Table 2, and these data support the suggestion made by several authors that the breeding range of the Ural Owl was more extensive in the past, particularly to the west (Voous, 1962; SAuer-Neubert, 1968; BecKer \& PiePer 1982; Pucher \& SChMitzBerger, 1999). The species was likely present in Switzerland at least during the 4th millennium $\mathrm{BC}$, and was probably widespread in Germany during the first millennium $\mathrm{AD}$ and possibly even during the medieval period.

\section{CONCLUSION}

The hypothesis that the carpometacarpus from Quaregnon represents a native bird is considered very probable, either as a migratory/ vagrant individual or as a local breeder. This is reinforced by other zooarchaeological finds outside the current breeding range in places broadly comparable to the Belgian locality in terms of latitude, altitude and habitat type. All these finds of Ural Owl support a wider westward distribution in the past, which was in all likelihood less fragmented than today and may have been continuous up to Western Europe. More zooarchaeological finds are necessary to further strengthen this hypothesis, and should ideally include bones of young birds, which would provide evidence that the Ural owl was breeding in the vicinity of the site.

\section{ACKNOWLEDGMENTS}

This study was carried out within the framework of a collaboration between the Royal Belgian Institute of Natural Sciences and the Direction de l'Archéologie Wallonne, financed by the Walloon 


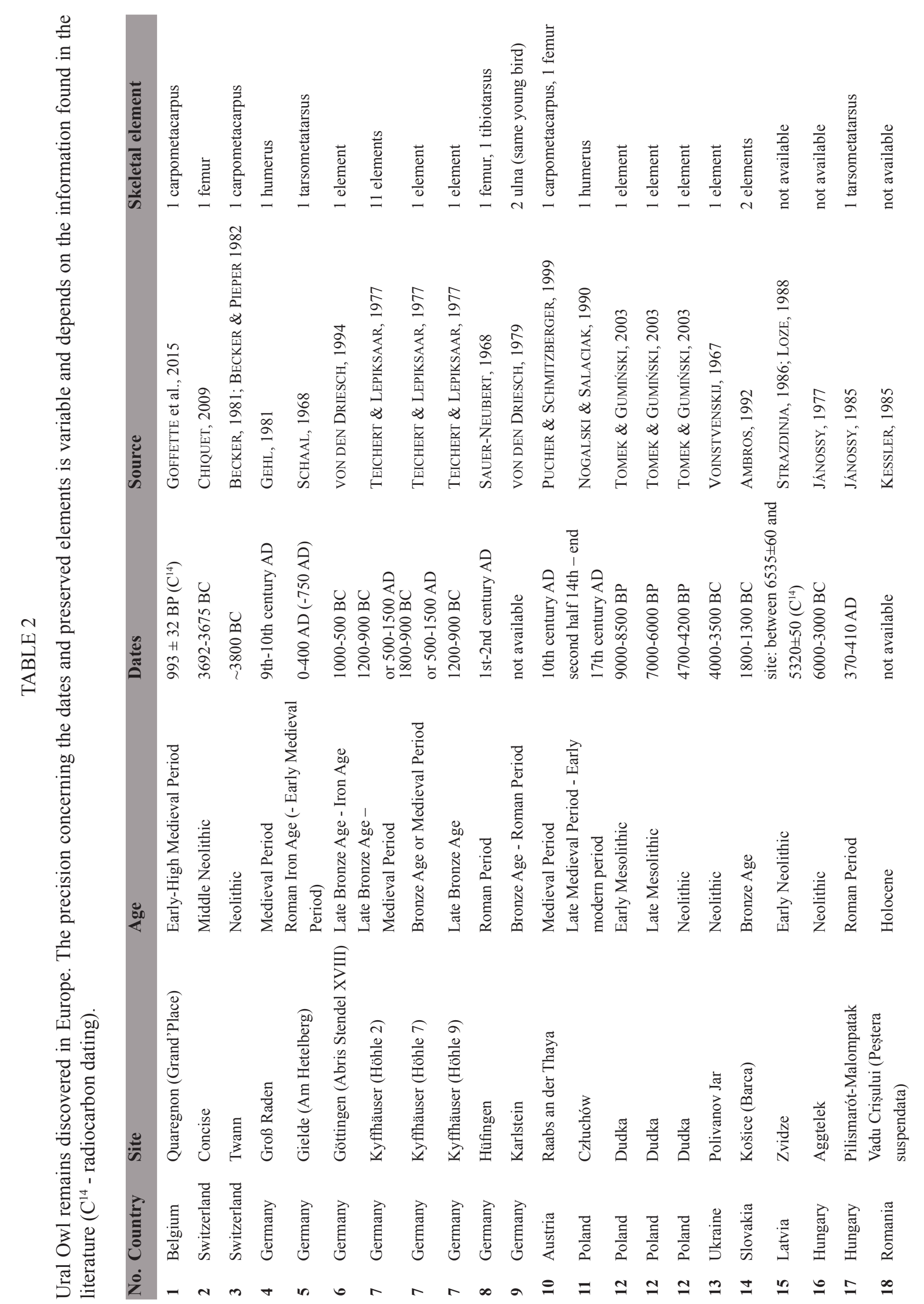


Region. We thank Cécile Mourer-Chauviré (French National Centre for Scientific Research) and Zbigniew Bocheński (Polish Academy of Sciences) for their feedback on the bone find and for providing us with measurements of modern bones stored respectively in the Regalia collection of the Institut de Paléontologie Humaine, Muséum national d'Histoire naturelle in Paris and in the Institute of Systematics and Evolution of Animals, Polish Academy of Sciences in Warsaw. We also thank Baudouin Van den Abeele (UCLouvain) for informing us about the medieval trade in birds of prey as well as about their use for falconry, and Norbert Benecke (Deutsches Archäologisches Institut) and Jeno Kessler (Eötvös Lorand University Budapest) for giving us complementary information on some finds. Finally, we would like to thank Anne-Marie Wittek (ADIA, Association pour la Diffusion de l'Information Archéologique) for modifying the map in Figure 1, as well as John R. Stewart (Bournemouth University), Didier Vangeluwe (RBINS) and Alain de Broyer (Aves/Natagora) for their valuable comments on a previous version of the manuscript and the reviewers for their constructive suggestions.

\section{REFERENCES}

Ambros C (1992). Tierreste aus neolithischen, äneolithischen und bronzezeitlichen Siedlungen in der Slowakei (Katalog). Manuskript Archäologisches Institut der Slowakischen Akademie der Wissenschaften, Nitra.

BASHTA AT (2009). Ural Owl Strix uralensis Population Dynamics and Range Expansion in Western Ukraine. Ardea, 97: 483-487.

BAUMEL JJ (1993). Handbook of avian anatomy: nomina anatomica avium. Publications of the Nuttall Ornithological Club, 23.

BECKER C (1981). Tierknochenfunde. Dritter Bericht. Die neolithischen Ufersiedlungen von Twann, 11: 1-206.

BECKER C \& PIEPER H (1982). Zum Nachweis des Habichtkauzes Strix uralensis in einer neolithischen Seeufersiedlung der Schweiz. Der Ornithologische Beobachter, 79: 159-162.
BENECKE N (1999). The project „The Holocene History of the European Vertebrate Fauna“. In: Benecke N (ed.), The Holocene History of the European Vertebrate Fauna. Modern Aspects of Research, Marie Leidorf: 151-161.

Bolboaca LE, Baltag EȘ, Pocora V \& ION C (2013). Habitat selectivity of sympatric Tawny Owl (Strix aluco) and Ural Owl (Strix uralensis) in hill forests from north-eastern romania. Analele Ştiinţifice ale Universităţii „Alexandru Ioan Cuza” din Iași, s. Biologie animală, 59: 69-76.

CAMPBELl KE \& BocheŃSKi ZM (2010). A new genus for the extinct Late Pleistocene owl Strix brea Howard (Aves: Strigiformes) from Rancho La Brea, California. In: BOLES WE \& WORTHY $\mathrm{TH}$ (eds), Proceedings of the VII International Meeting of the Society of Avian Paleontology and Evolution. Records of the Australian Museum, 62: 123-144.

Chiquet PA (2009). La faune du Néolithique moyen de Concise (Vaud, Suisse) : analyse des modes d'exploitation des ressources animales et contribution à l'interprétation de l'espace habité. $\mathrm{PhD}$ thesis, Genève University.

CRAMP S (1985). The Birds of the Western Palearctic. Volume IV: Terns to Woodpeckers, Oxford Univiversity Press, Oxford.

CRAMP S \& SIMMONS KEL (1977). The Birds of the Western Palearctic. Volume I: Ostriches to Ducks, Oxford University Press, Oxford.

Del Hoyo J, Elliott A \& Sargatal J (1999). Handbook of the Birds of the World. Volume 5: Barn-owls to Hummingbirds, Lynx Edicions, Barcelona.

DENIS M (2010). Quaregnon/Quaregnon : fouilles préventives aux abords de la tour Saint-Quentin, campagne 2008. Chronique de l'Archéologie wallonne, 17: 89-91.

DENIS M (2011). Quaregnon/Quaregnon : fouilles préventives sur la Grand'Place, campagne 2009. Chronique de l'Archéologie wallonne, 18: 98-99.

DORNBUSCH M (1990). Ein interessanter Ringfund: Habichtskauz-Nachweis (Ringfund mitteilung der Vogelwarte Hiddensee 1/1990). Der Falke, 37: 300-301.

FERRARIS JJF (1771-1778). Carte de Cabinet des Pays-Bas autrichiens, Mons, pl. 54. Koninklijke Bibliotheek van België (Internet adress : http:// www.kbr.be/collections/cart_plan/ferraris/ ferraris_fr.html). 
GAUTIER A (1987). Taphonomic groups, how and why? Archaeozoologica, 12: 47-52.

GEHL O (1981). Groß Raden. Haustiere und Jagdwild der slawischen Siedler. Beiträge zur Ur- und Frühgeschichte der Bezirke Rostock, Schwerin und Neubrandenburg, 13.

GofFetTe Q, Denis M \& Wouters W (2015). Quaregnon/Quaregnon : Etude des restes fauniques de la fin du premier Moyen Age $\left(9^{\mathrm{e}}-11^{\mathrm{e}}\right.$ siècle) découverts lors des fouilles de la Grand'Place en 2008 et 2009. Chronique de l'Archéologie Wallonne, 22: 114-117.

HAUSKNECHT R, JaCOBS S, MÜLleR J, ZINK R, Frey H, Solheim R, Vrezec A, Kristin A, Minok J, Kergalve I, Saurola P \& KuehN R (2014). Phylogeographic analysis and genetic cluster recognition for the conservation of Ural Owls (Strix uralensis) in Europe. Journal of Ornithology, 155: 121-134.

JAQUES SD \& DOBNEY K (2002). Avian signatures for identity and status in Anglo-Saxon England. Acta Zoologica Cracoviensia, 45: 7-21.

JÁNOSSY D (1977). Plio-Pleistocene bird remains from the Carpathian Basin III. Strigiformes, Falconiformes, Caprimulgiformes, Apodiformes. Aquila, 84: 9-36.

JÁNOSSY D (1985). Wildvogelreste aus archäologischen Grabungen in Ungarn (Neolithicum bis Mittelalter). Fragmenta mineralogica et Palaeontologica, 12: 67-103.

KESSLER E (1985). Contribuţii noi la studiul avifaunelor cuaternare din România. Crişia, 15: 485-491.

KeSSLER J (2014). Fossil and Subfossil Bird Remains and Faunas from the Carpathian Basin. Ornis Hungarica, 22: 65-125.

Kristin A, Minok J, DANKo S, Karaska D, PaCENOVSKy S, SANiga M, Bodova M, Balazs C, Sotnar K, Kornan J \& Oleksak M (2007). Distribution, abundance and conservation of the Ural Owl Strix uralensis in Slovakia. In : MULLER J, SCHREZINGER W, MONING C (eds.), European Ural Owl workshop, Praga. Tagungsbericht, 8: 8-15.

LANGER G (1980). Vergleichend morphologische Untersuchungen an Einzelknochen in Mitteleuropa vorkommender mittelgrosser Eulenarten. PhD thesis, München University.
LOZE IA (1988). Poselenija kamennogo veka Lubanskoj Niziny: Mezolit, pannij i srednij neolit. Riga.

LUNDBERG A \& WestMAN B (1984). Reproductive success, mortality and nest site requirements of the Ural Owl Strix uralensis in central Sweden. Annales Zoologici Fennici, 21: 265-269.

LYMAN RL (2006). Paleozoology in the Service of Conservation Biology. Evolutionary Anthropology, 15: 11-19.

MEBS T \& SCHERZINGER W (2006). Rapaces nocturnes de France et d'Europe. Delachaux et Niestlé, Neuchâtel.

MikKola H (1983). Owls of Europe. T \& A D Poyser, Calton.

NiKULINA EA \& SCHMÖLCKE U (2015). First archaeogenetic results verify the mid-Holocene occurrence of Dalmatian pelican Pelecanus crispus far out of present range. Journal of Avian Biology, 46: 1-8.

NogALSKI S \& SAŁACIAK A (1990). Szczątki kostne ptaków w materiałach wykopaliskowych z Człuchowa. Roczniki Akademii Rolniczej w Poznaniu, 206 (Archeozoologia, 14): 51-67.

OGGINS RS (2004). The Kings and Their Hawks: Falconry in Medieval England. Yale University Press, Yale.

PIEHLER HM (1976). Knochenfunde von Wildvögeln aus archäologischen Grabungen in Mitteleuropa. $\mathrm{PhD}$ thesis, München University.

Pucher E \& SCHMitzberger M (1999). Ein mittelalterlicher Fundkomplex aus Nieder österreich mit hohem Wildanteil: Die Flur Sand bei Raabs a.d. Thaya. In: BECKER C (ed.), Historia animalium ex ossibus. Beiträge zur Paläoanatomie, Archäologie, Ägyptologie, Ethnologie und Geschichte der Tiermedizin (Festschrift für Angela von den Driesch zum 65. Geburtstag): 355-378.

SAUER-NEUBERT A (1968). Tierknochenfunde aus der römischen Zivilsiedlung in Hüfingen. II. Wildund Haustierknochen mit Ausnahme der Rinder. Dissertation, $\mathrm{PhD}$ thesis, München University.

SCHAAL F (1968). Tierknochenfunde aus der Siedlung "Am Hetelberg" bei Gielde/Niedersachsen. Dissertation $\mathrm{PhD}$ thesis, München University.

SCHERZINGER W (2006). Die Wiederbegründung des Habichtskauz-Vorkommens Strix uralensis im Böhmerwald Ornithologischer Anzeiger, 45: 97156. 
SERJEANTSON D (2006). Birds: food and mark of status. In: WoOlgar CM, SerJeantson D \& WALDRON T (eds), Food in medieval England, diet and nutrition: 131-147.

STEWART JR (2005). The use of modern geographical ranges in the identification of archaeological bird remains. In: GRUPE G \& PETERS J (eds), Feathers, grit and symbolism. Birds and humans in the ancient Old and New Worlds, Marie Leidorf: 4354.

STEWART JR (2007). The fossil and archaological record of the Eagle Owl in Britain. British Birds, 100: 481-486.

STEWART JR, Lister AM, BARNES I \& DALÉN L (2010). Refugia revisited: individualistic responses of species in space and time. Proceeding of the Royal Society B, 277: 661-671.

STRAZDINJA A (1986). Ostatki ptic v kul'turnych slojach mezolitčeskich stojanok Lubanskoj niziny Latvijskoj SSR. Izučenie ptic, ich ochrana i racional'noe ispol'zovanie: 262-263.

TEICHERT M\& LEPIKSAAR J(1977). Die Vogelknochen aus den urgeschichtlichen Kulthöhlen des Kyffhäusergebirges. Alt-Thüringen, 14: 108-144.

TOMEK T \& GuMiŃSKI W (2003). Bird remains from the Mesolithic and Neolithic Site Dudka, Masuria, NE Poland. Acta Zoologica Cracoviensia, 46: 9-18.

TYRBERG T (2002). The archaeological record of domesticated and tamed birds in Sweden. Acta Zoologica Cracoviensia, 45: 215-231.

VAlKama J, SAURola P, Lehikoinen A, Lehikoinen E, Piha M, Sola P \& Velmala W (2014). The Finnish Bird Ringing Atlas. Vol II. Finnish Museum of Natural History and Ministry of Environment, Helsinki.

Vanpoucke S, Pigière F, Defgnée A \& VAn Neer W (2007). Pig husbandry and environmental conditions in Northern Gaul during Antiquity and the Early Middle Ages: the contribution of hypoplasia analysis. Archaeofauna, 16: 7-20.
Verhulst A (1999). Précis d'histoire rurale de la Belgique, Éditions de l'Université, Bruxelles.

VOINSTVENSKIJ MA (1967). Iskopaemaja ornitofauna Ukrainy. Prirodnaja obstanovka i fauny prošlogo, 3: 3-76.

VON DEN DRIESCH A (1976). A guide to the measurement of animal bones from archaeological sites. Peabody Museum Bulletins, Yale.

VON DEN DRIESCH A (1979). Tierknochenfunde aus Karlstein, Ldkr. Berchtesgadener Land. Bayerische Vorgeschichtsblätter, 44: 149-170.

VON DEN DRIESCH A (1994). Vogelknochen aus Abris im Rheinhäuser Wald, Ldkr. Göttingen. Veröffentlichungen der urgeschichtlichen Sammlungen des Landesmuseums Hannover, 43: 127-139.

VON DEN DRIEsch A \& PÖllath N (2010). Distribution history of European wild birds based on archaeozoological records. A contribution to human-bird relationships in the past. In: Grupe G, McGlynn G \& Peters J (eds), Archaeobiodiversity: A European perspective: 71-216.

Voous KH (1962). Die Vogelwelt Europas. Hamburg/Berlin.

VREZEC A \& TOME D (2004). Altitudinal segregation between Ural Owl Strix uralensis and Tawny Owl $S$. aluco: evidence for competitive exclusion in raptorial birds. Bird Study, 51: 264-269.

Received: June 29th, 2015

Accepted: September 22nd, 2015

Branch editor: Diederik Strubbe 